Original Article

\title{
Trichinellosis surveillance in wildlife in northeastern argentine patagonia
}

\author{
M. Winter ${ }^{\mathrm{a}, \mathrm{b}, *}$, M. Pasqualetti ${ }^{\mathrm{c}, \mathrm{d}}$, F. Fariña ${ }^{\mathrm{c}, \mathrm{d}}$, M. Ercole $^{\mathrm{c}}$, M. Failla $^{\mathrm{e}, \mathrm{g}}$, M. Perello $^{\mathrm{f}}$, D. Birochio $^{\mathrm{a}, \mathrm{b}}$, \\ S. Abate ${ }^{\mathrm{a}, \mathrm{b}}$, M. Soricetti ${ }^{\mathrm{a}, \mathrm{b}}$, M. Ribicich ${ }^{\mathrm{c}, \mathrm{d}}$ \\ ${ }^{a}$ Universidad Nacional de Río Negro- Sede Atlántica, Viedma, Río Negro, Argentina \\ ${ }^{\mathrm{b}}$ Centro de Investigacióny Transferencia Río Negro, Viedma, Río Negro, Argentina \\ c Universidad de Buenos Aires. Facultad de Ciencias Veterinarias. Cátedra de Parasitología y Enfermedades Parasitarias, Av. Chorroarín 280, C1427CWO CABA, \\ Argentina \\ d CONICET - Universidad de Buenos Aires, Instituto de Investigaciones en Producción Animal (INPA), Av. Chorroarín 280, C1427CWO, Buenos Aires, Argentina \\ e Proyecto Patagonia Noreste. Balneario El Cóndor, Río Negro, Argentina \\ ${ }^{\mathrm{f}}$ Fundación Félix de Azara, Ciudad Autónoma de Buenos Aires, Argentina \\ ${ }^{\mathrm{g}}$ Museo Provincial Patagónico de Ciencias Naturales Juan Carlos Salgado, General Roca, Río Negro, Argentina
}

\section{A R T I C L E I N F O}

\section{Keywords:}

Trichinellosis

Trichinella

Zoonosis

Wildlife

Patagonia

Argentina

\begin{abstract}
A B S T R A C T
Trichinellosis is a food-borne parasitic disease produced by different nematodes of the genus Trichinella. In Argentina, it is an endemic zoonosis and an important public health problem. The infection has been detected in domestic and wild animals. Trichinella spp. muscle larvae have anaerobic metabolism, which allows their survival in decaying tissues. The aim of this study was to evaluate the presence of Trichinella spp. in carnivorous and/or scavenger wild vertebrates - birds, mammals and reptiles - in northeastern Argentine Patagonia. Skeletal muscle samples from 141 animals, which were found killed on northeastern Argentine Patagonia roads, were analyzed by the artificial digestion method. None of the 141 samples were positive for larvae of Trichinella. These results suggest that Trichinella does not use these species to complete its cycle in this region of the continent and the absence of a significant alteration in the study area makes it difficult to transmit parasitic diseases. However, due to the limited number of samples assessed for some species, this could not be confirmed. The relevance of this study resides in the fact that it is the first systematic study in South America that considers birds, reptiles and mammals as potential hosts for Trichinella.
\end{abstract}

\section{Introduction}

Trichinellosis is a food-borne parasitic disease produced by different nematodes of the genus Trichinella. It currently behaves as a re-emergent zoonosis with wide global distribution. This parasite has been reported in domestic and wild animals on all continents, except Antarctica (Dupouy-Camet and Murrell, 2007). Trichinellosis worldwide distribution is associated with the ability of Trichinella spp. to affect a large number of hosts that exceeds 100 species among mammals, birds and reptiles (Pasi et al., 2016). Until now, 12 species and genotypes of the genus Trichinella are recognized in the world grouped in two clades, the encapsulated clade, which included T. spiralis, $T$. nativa, T. britovi, T. murrelli, T. nelsoni, and T. patagoniensis; and three genotypes (Trichinella T6, T8 and T9), and the non-encapsulated clade, which included T. pseudospiralis, T. papuae and T. zimbabwensis (Pozio and Murrell, 2006; Zarlenga et al., 2006; Krivokapich et al., 2012). Encapsulated species have been found naturally only in mammalian muscle, whereas non-encapsulated species have been found naturally in mammals, birds, and reptiles (Pozio and Zarlenga, 2013), shown a high host range. In South America, trichinellosis is an endemic disease in countries such as Argentina and Chile (Ribicich et al., 2005). In Argentina, this parasitic disease is an important public health problem because of its high morbidity rates (Pasqualetti et al., 2014). Although almost human outbreaks are related to the consumption of domestic pig (Ribicich et al., 2005), in recent years, human cases of trichinellosis have been reported by consumption of cougar Puma concolor or wild boar Sus scrofa meat (Ribicich et al., 2010b; Pasqualetti et al., 2014). Several studies have detected Trichinella spp. in wild animals such as rodents species, wild boar Sus scrofa, big hairy armadillo Chaetophractus villosus, cougar Puma concolor (Tesón et al., 1997; García et al., 2005; Krivokapich et al., 2006; Ribicich et al., 2010a) white-eared opossum Didelphis albiventris and little water opossum Lutreolina crassicaudata (Castaño Zubieta et al., 2014). However, so far very little is known about the wild Cycle of Trichinella genus in Argentina.

\footnotetext{
* Corresponding author at: Alem 665, Viedma, Río Negro, Argentina.

E-mail addresses: mwinter@unrn.edu.ar (M. Winter), mpasqualetti@fvet.uba.ar (M. Pasqualetti), fernandoaf@fvet.uba.ar (F. Fariña), mercole@fvet.uba.ar (M. Ercole), dbirochio@unrn.edu.ar (D. Birochio), sabate@unrn.edu.ar (S. Abate), msoricetti@unrn.edu.ar (M. Soricetti), mribicich@fvet.uba.ar (M. Ribicich).
} 
In adittion, Trichinella spp. muscle larvae have an anaerobic metabolism in the tissue of their host (Despommier, 1990) that allow their survival in decaying tissues and serving as a source of infection in scavenger species. Encapsulated species show more persistence in decaying tissue (Stewart et al., 1990; Owen and Reid, 2007). Trichinella patagoniensis, which is the last encapsulated species described, is endemic to South America, and has been found only in cougars (Krivokapich et al., 2012). Also, it has been demonstrated in vitro that larvae of this new species are able to survive up to three weeks in decaying tissue and maintain their infective capacity for two weeks in decaying tissue (Fariña et al., 2016). The persistence of Trichinella spp. in decaying tissue also changes according to different environmental conditions: low temperature and high humidity favor survival of Trichinella larvae even when the muscle tissue is completely liquefied (Pozio, 2016). Recently, it has been determined that species with scavenger habits have a more important epidemiological role than predatory species in the Trichinella Wild Cycle (Pozio, 2016). Also, it is recognized that wild carnivores and omnivorous sustain the Trichinella spp. biomass (Pozio and Zarlenga, 2013), and some wild mammals constitute the best reservoir for this parasite (Campbell, 1988). Therefore, it is important to carry out surveillance studies to determinate the presence and circulation of Trichinella spp. in wildlife and know the spatial distribution of Trichinella spp. in the northeastern Patagonia. Also, it is important to investigate if T. patagoniensis may infect other sympatric hosts with Puma concolor in this region. The aim of this study was to evaluate the presence of Trichinella spp. in carnivorous and/or scavenger wild vertebrates - birds, mammals and reptiles - in the northeastern Argentine Patagonia.

\section{Material and methods}

\subsection{Study area}

The study was carry out in the northeastern Argentine Patagonia that includes the south of Buenos Aires province and the northeastern of Rio Negro province. This is a transitional area between Espinal and the Monte regions (Roig et al., 2009). The extensive ecotone is characterized by the transition from xerophilous forest to xerophila shrub (Fosberg, 1961). The vegetation is distributed as shrub-graminous islands dispersed in a soil matrix with little or no vegetation cover (Aguiar and Sala, 1998). The herbaceous stratum is formed by winter growth grassland. Most of the area are private fields, where the native vegetation alternates with semi-extensive livestock (bovine, ovine and porcine) and farming production. The weather is sub-temperate dry transition, with warm summers and moderate winters, and without any seasonal excess of water. The seasons with the highest precipitations are autumn and spring, although in winter it can rain occasionally. Windy, especially in spring and summer (Bran et al., 2000). Average annual temperatures range from $10^{\circ}$ to $14^{\circ} \mathrm{C}$ (Rey et al., 1988).

Patagonian wildlife shows a lower number of species than other regions of the country, and even than other ecologically similar regions of the world. However, there are very characteristic groups of great ecological significance and more abundance of native and endemic species than other parts of the world like Lycalopex griseus, Dolichotis patagonum, Leopardus geoffroyi, Leopardus colocolo, Galictis cuja and Lyncodon patagonicus. (Bonino, 2003). Wildlife animals coexist with livestock in peri-urban areas. The presence of cougars and wildboars are recognized and they are frequently hunting prey destined for consumption. Also, pig farms with risk factor associated with Trichinella infection are frequent in this area.

\subsection{Muscle samples and artificial digestion}

Samples of skeletal muscle from carnivorous and/or scavenger wild vertebrates - birds, mammals and reptiles - found as road-kill on national and provincial routes and rural roads of northeastern Argentine
Patagonia were taken between April of 2015 and February of 2017. Dead animals were found randomly by the authors. Muscle samples of mammals were collected from tongue, anterior and/or posterior limbs and intercostal muscles. For birds were collected from limbs, tongue and pectoral muscles, and in reptiles were collected from axial musculature. Samples were kept at $4{ }^{\circ} \mathrm{C}$ until the laboratory and were processed by artificial digestion method (Gamble et al., 2000). Digestion assays are the only reliable procedures for the direct detection of Trichinella larvae in meat (Gamble et al., 2000; OIE, 2008).

Identification of the mammals, birds and reptiles was performed according to Chebez et al., 2014; Ferguson-Lees and Christie, 2001; König and Weick, 2008; Hoyo et al., 1992, 1996, 1997 and Scrocchi et al., 2010.

The collection protocol was approved by Secretary of Environment and Sustainable Development of Rio Negro province (085026-SAYDS019/2015).

\section{Results}

A total of 141 wild vertebrate samples were analyzed: 94 mammals, 37 birds and 9 reptiles that covered an area of $105 \mathrm{~km}^{2}$ in northeastern Argentine Patagonia. All the species analyzed are endemics, and none of them is at risk of conservation. All the samples were Trichinella spp. negative. Table 1 shows the species, number of individuals by species and their eating habits. Fig. 1 shows the distribution of sampling points.

\section{Discussion}

In Argentina, the most important source of human trichinellosis infection is the domestic pig (Ribicich et al., 2005). In the study area, more than $50 \%$ of pig production is slaughtered and traded informally

Table 1

Species and number of each specie analyzed and description of their eating habits. $\mathrm{C}=$ carnivorous; $\mathrm{O}=$ omnivorous; $\mathrm{H}=$ hunter; $\mathrm{S}=$ scavenger.

\begin{tabular}{|c|c|c|c|c|}
\hline \multirow{2}{*}{$\begin{array}{l}\text { Scientific name } \\
\text { Mammals n total }=94\end{array}$} & \multirow[t]{2}{*}{ Common name } & \multirow[t]{2}{*}{$\mathrm{n}$} & \multicolumn{2}{|c|}{ Eating habits } \\
\hline & & & $\mathrm{C} / \mathrm{O}$ & $\mathrm{H} / \mathrm{S}$ \\
\hline \multicolumn{5}{|l|}{ Didelphimorphia } \\
\hline Didelphis albiventris & white-eared opossum & 15 & $\mathrm{O}$ & $\mathrm{S}$ \\
\hline \multicolumn{5}{|l|}{ Cingulata } \\
\hline Chaetophractus vellosus & big hairly armadillo & 19 & $\mathrm{O}$ & $S$ \\
\hline \multicolumn{5}{|l|}{ Carnivora } \\
\hline Leopardus geoffroyi & geoffroy's cat & 10 & $\mathrm{C}$ & $\mathrm{H}$ \\
\hline Galictis cuja & lesser grison & 13 & $\mathrm{C}$ & $\mathrm{H}$ \\
\hline Conepatus chinga & molina's Hog-nosed Skunk & 1 & $\mathrm{O}$ & S \\
\hline Lycalopex gymnocercus & south american grey fox & 35 & $\mathrm{O}$ & S \\
\hline Birds $\mathrm{n}$ total $=37$ & & & $\mathrm{C} / \mathrm{O}$ & $\mathrm{H} / \mathrm{S}$ \\
\hline \multicolumn{5}{|l|}{ Procellariiformes } \\
\hline Macronectes giganteus & southern giant petrel & 1 & $\mathrm{C}$ & $\mathrm{H}$ \\
\hline \multicolumn{5}{|l|}{ Falconiformes } \\
\hline Cathartes aura & turkey vulture & 1 & $\mathrm{C}$ & S \\
\hline Buteo polysoma & red backed hawk & 2 & $\mathrm{C}$ & $\mathrm{H}$ \\
\hline Polyborus plancus & southern crested caracara & 1 & $\mathrm{C}$ & S \\
\hline Milvago chimango & chimango caracara & 2 & $\mathrm{O}$ & S \\
\hline Falco sparverius & american kestrel & 1 & $\mathrm{C}$ & $\mathrm{H}$ \\
\hline \multicolumn{5}{|l|}{ Charadriformes } \\
\hline Larus dominicanus & kelp gull & 4 & $\mathrm{O}$ & S \\
\hline Sterna hirudinacea & south american tern & 1 & $\mathrm{C}$ & $\mathrm{H}$ \\
\hline \multicolumn{5}{|l|}{ Cuculiformes } \\
\hline Guira guira & guira cuckoo & 2 & $\mathrm{O}$ & $\mathrm{S}$ \\
\hline \multicolumn{5}{|l|}{ Strigiformes } \\
\hline Tyto alba & barn owl & 9 & $\mathrm{C}$ & $\mathrm{H}$ \\
\hline Athene cunicularia & burrowing owl & 9 & $\mathrm{C}$ & $\mathrm{H}$ \\
\hline Asio flammeus & short eared owl & 2 & $\mathrm{C}$ & $\mathrm{H}$ \\
\hline Bubo virginianus & great horned owl & 2 & $\mathrm{C}$ & $\mathrm{H}$ \\
\hline \multicolumn{4}{|l|}{ Squamata } & $\mathrm{H} / \mathrm{S}$ \\
\hline Philodryas patagoniensis & parejera culebra & 9 & $\mathrm{C}$ & $\mathrm{H}$ \\
\hline
\end{tabular}




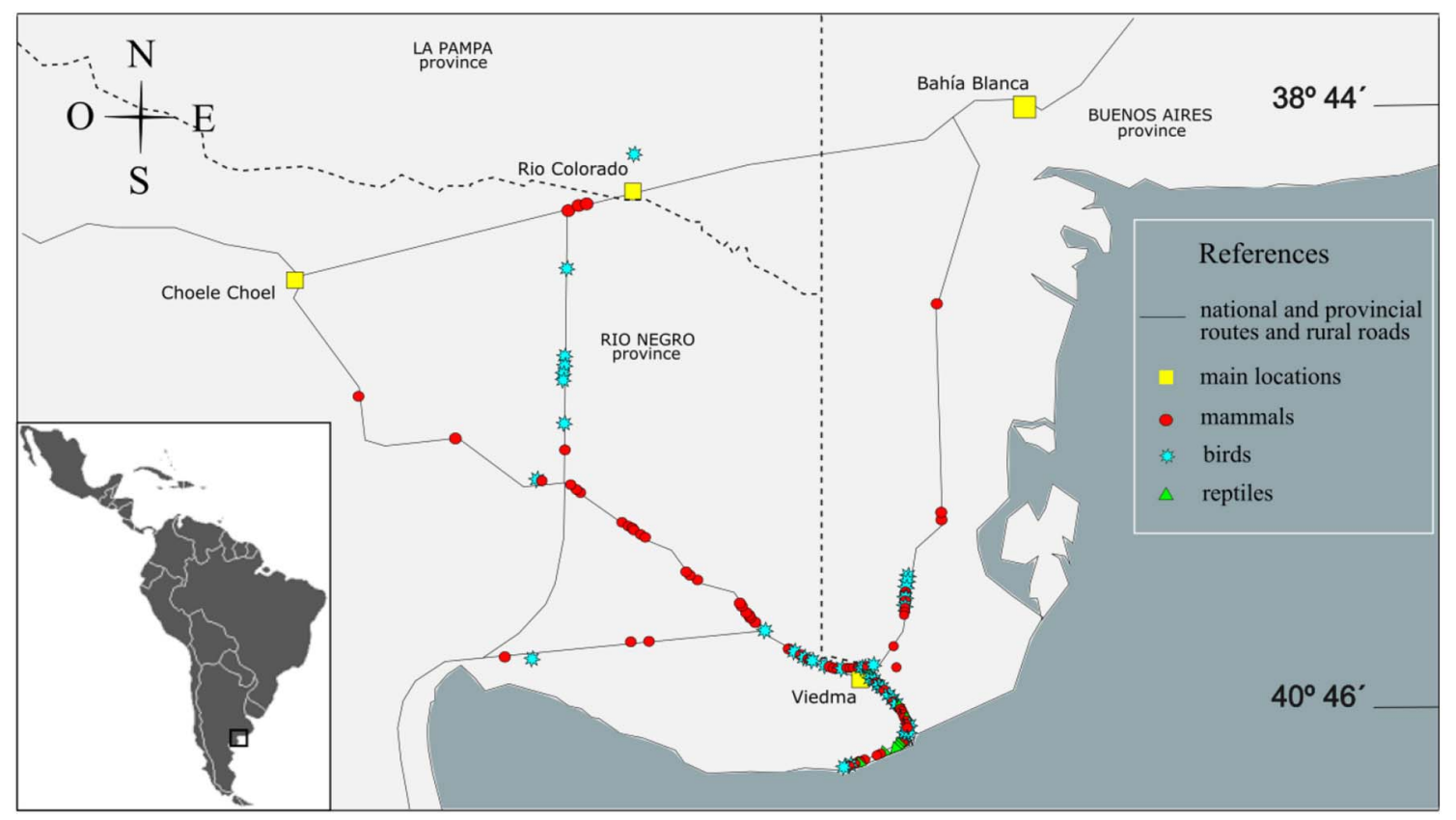

Fig. 1. Location of the study area and distribution of sampling points in northeastern Argentine Patagonia.

and most of the rural population of the region practice traditionally inherited pig production methods in the absence of adequate sanitary controls (Mohor, 2015). In this context, wild animals in search of food could participate in the life Cycle of Trichinella spp. Experimental studies in domestic cats have demonstrated that this specie is susceptible and supportive hosts for Trichinella patagoniensis (Ribicich et al., 2013), this was evidenced by the high reproductive capacity of the organism compared with that observed in rats and pigs where Trichinella patagoniensis showed poor or null reproductive capacity (Gonzalez Prous et al., 2011). The negative results observed in the totality of the samples could be indicate that the parasite does not use these species to complete its cycle in this region of Argentina. However, due to the limited number of samples assessed for some species this can not be confirmed. These results agree with the absence of evidence of circulation of Trichinella spp. in hunting wild species, as in the case of wild boar (Winter et al., 2015; Winter et al., 2016).

Numerous studies argue that the presence of pathogens in wildlife is associated with the degree of habitat fragmentation and degradation. Wildlife of degraded areas are at increased risk of infection. In addition, the sudden elimination of a habitat may cause the migration of animals from one area to another, along with its associated pathogens. So, hostpathogen dynamics between wild species, between wild species and domestic species, and between wild species and man, may be seriously affected as a result of the alteration, fragmentation or elimination of natural habitats (Weiss, 2001; Gillespie and Chapman, 2006; Langlois et al., 2001; Ostfeld and Keesing, 2000). Our results allow us to consider that the study area maintains as a conserved natural area and the absence of a significant alteration makes it difficult to transmit parasitic diseases between domestic and wild species.

The use of road-killed animals may allow to obtain information about the role of wild animals in the transmission Cycle of Trichinella and other infections and parasitic diseases and, hence, contribute to anticipate outbreaks in livestock and human population.

This is the first systematic study in South American to assess the presence of Trichinella spp. in wild birds, reptiles and mammals and more investigations are necessary in areas no explored of the continent to stablish the role of animals species involved with new Trichinella species.

\section{Funding}

This study was supported by FONCyT ANPCyT PICT- 2013-0965 and PICT2015-2350.

\section{References}

Aguiar, M.R., Sala, O.E., 1998. Interactions among grasses, shrubs and herbivores in Patagonia grass shrubs steppes. Ecologia Austral. 8, 201-210.

Bonino, N.A., 2003. Fauna silvestre de la Patagonia. In: Comunicación Técnica nº 117. INTA-EEA, Bariloche, Área de recursos naturales. Fauna (ISSN 1667-4006).

Bran, D., Ayesa, J.A., Lopez, C., 2000. Áreas Ecológicas de Río Negro. Laboratorio de Teledetección-SIG INTA-EEA, Bariloche. http://sipan.inta.gob.ar/productos/ssd/rn/ ae.htm.

Campbell, W.C., 1988. Trichinosis revisited another look at modes of transmission. Parasitol. Today 4 (3), 83-86.

Castaño Zubieta, R., Ruiz, M., Morici, G., Lovera, R., Fernández, M.S., Caracostantogolo, J., Cavia, R., 2014. First report of Trichinella spiralis from the white-eared (Didelphis albiventris) and the thick-tailed opossum (Lutreolina crassicaudata) in central Argentina. Helminthologia 51 (3), 198-202.

Chebez, J.C., Pardiñas, U., Teta, P., 2014. In: Massini, Vasquez (Ed.), Mamíferos Terrestres Patagonia Sur de Argentina y Chile, pp. 208 (Ciudad Autónoma de Buenos Aires).

Despommier, D.D., 1990. Trichinella spiralis: the worm that would be virus. Parasitol. Today 6, 193-196.

Dupouy-Camet, J., Murrell, K.D., 2007. In: Dupouy-Camet, J., Murrell, K.D. (Eds.), FAO/ WHO/OIE Guidelines for the Surveillance, Management, Prevention and Control of Trichinellosis, Chapter 1. FAO/WHO/OIE. http://www.trichinellosis.org/uploads/ FAO-WHO-OIE_Guidelines.pdf.

Fariña, F., Pasqualetti, M., Ilgová, J., Cardillo, N., Ercole, M., Aronowicz, T., Krivokapich, S., Kašný, M., Ribicich, M., 2016. Evaluation of the infectivity and the persistence of Trichinella patagoniensis in rotten guinea pig (Cavia porcellus) muscle tissue. Parasitol. Res. 116 (1), 371-375.

Ferguson-Lees, J., Christie, D.A., 2001. Raptors of the World. (Houghton Mifflin Harcourt).

Fosberg, F.R., 1961. Classification of vegetation for general purposes. Trop. Ecol. 2, 1-28. Gamble, H.R., Bessonov, A.S., Cuperlovic, K., Gajadhar, A.A., Van Knapen, F., Noeckler, K., Schenone, H., Zhu, X., 2000. International commission on Trichinellosis: recommendations on methods for the control of Trichinella in domestic and wild animals intended for human consumption. Vet. Parasitol. 93, 393-408.

García, E., Mora, L., Torres, P., Jercic, M.I., Mercado, R., 2005. First record of human trichinosis in Chile associated with consumption of wild boar (Sus scrofa). Mem. Inst. Oswaldo Cruz 100 (1), 17-18.

Gillespie, T.R., Chapman, C.A., 2006. Prediction of parasite infection dynamics in primate metapopulation based attributes of forest fragmentation. Conserv. Biol. 20, 441-448.

Gonzalez Prous, C., Gatti, G., Ribicich, M.M., Pasqualetti, M., Rosa, A., Krivokapich, S.J., 2011. Estudio de la capacidad reproductiva de Trichinella T12. I Congreso Internacional de Zoonosis y Enfermedades Emergentes-VII Congreso Argentino de Zoonosis. V92-29119. pp. 223 (Buenos Aires, Argentina).

Hoyo, J., Elliott, A., Sargatal, J., 1992. Handbook of the Birds of the World. vol. 1. Lynx/ 
Bird Life International, pp. 696.

Hoyo, J., Elliott, A., Sargatal, J., 1996. Handbook of the Birds of the World. vol.3. Lynx/ Bird Life International, pp. 821.

Hoyo, J., Elliott, A., Sargatal, J., 1997. Handbook of the Birds of the world. vol. 4. Lynx/ Bird Life International, pp. 679.

König, C., Weick, F. (Eds.), 2008. Owls of the World. A\&C Black, pp. 528.

Krivokapich, S.J., Molina, V., Bergagna, H.F.J., Guarnera, E.A., 2006. Epidemiological survey of Trichinella infection in domestic, synanthropic and sylvatic animals from Argentina. J. Helminthol. 80 (3), 267-269.

Krivokapich, S.J., Pozio, E., Gatti, G.M., Gonzalez Prous, C.L., Ribicich, M., Marucci, G., La Rosa, G., Confalonieri, V., 2012. Trichinella patagoniensis n. Sp. (Nematoda), a new encapsulated species infecting carnivorous mammals in South America. Inter. J.Parasitol. 42 (10), 903-910.

Langlois, J.P., Fahrig, L., Merriam, G., Artsob, H., 2001. Landscape structure influences continental distribution of hantavirus in deer mice. Lanscape. Ecology 16, 255-266.

Mohor, S., 2015. Actividad Pecuaria en la provincia de Río Negro: Proyecto FAO UTF. ARG17. http://www.fao.org/fileadmin/user_upload/rlc/utf017arg/rionegro/DT_04 Actividad_pecuaria.pdf.

OIE, Office International des Epizooties, 2008. Chapter 2.1.16. Trichinellosis. In: Manual of Diagnostic Tests and Vaccines for Terrestrial Animals, pp. 344-352 (Paris).

Ostfeld, R.S., Keesing, F., 2000. Biodiversity and disease risk: the case of Lyme disease. Conserv. Biol. 14, 722-728.

Owen, I.L., Reid, S.A., 2007. Survival of Trichinella papuae muscle larvae in a pig carcass maintained under simulated natural conditions in Papua New Guinea. J. Helminthol. 81, 429-432.

Pasi, K.K., Pozio, E., La Rosa, G., Chang, B.C.H., Koehler, A.V., Hoberg, E.P., Boag, P.R., Tan, P., Jex, A.R., Hofmann, A., Sternberg, P.W., Young, N.D., Gasser, R.B., 2016. Phylogenomic and biogeographic reconstruction of the Trichinella complex. Nat. Commun. 7, 10513.

Pasqualetti, M., Acerbo, M., Miguez, M., Rosa, A., Fariña, F., Cardillo, N., Degregorio, O., Ribicich, M., 2014. Nuevos aportes al conocimiento de Trichinella y trichinellosis. Rev. Med. Vet. 95 (2), 12-21.

Pozio, E., 2016. Adaptation of Trichinella spp. for survival in cold climates. Food and Waterborne Parasitol. 4, 4-12.

Pozio, E., Murrell, K.D., 2006. Systematics and epidemiology of Trichinella. Adv. Parasitol. $63,367-439$.

Pozio, E., Zarlenga, D.S., 2013. New species of the Trichinella puzzle. Int. J. Parasitol. 43 (12-13), 983-997.

Rey, H.D., Quiroga, J.O., Moldes de Entraigas, B., Peronja, A., Suárez, G.N., Entraigas, J.,
Bustos, J.A., Cardone, E. (Eds.), 1988. Historia del Valle Inferior del Río Negro. El nuevo distrito federal. Plus Ultra, Bueno Aires, Argentina, pp. 250.

Ribicich, M., Gamble, H.R., Rosa, A., Bolpe, J., Franco, A., 2005. Trichinellosis in Argentina: an historical review. Vet. Parasitol. 132, 137-142.

Ribicich, M., Gamble, H.R., Bolpe, J., Scialfa, E., Krivokapich, S., Cardillo, N., Betti, A., Cambiaggi Holzmann, M.L., Pasqualetti, M., Fariña, F., Rosa, A., 2010a. Trichinella infection in wild animals from endemic regions of Argentina. Parasitol. Res. 107, 377-380.

Ribicich, M., Rosa, A., Bolpe, J., Scialfa, E., Cardillo, N., Pasqualetti, M.I., Betti, A., Fariña, F., Vizio, E., Gimenez, R., Pascual, G., Borrás, P., Aronowicz, T., 2010b. Avances en el estudio del diagnóstico y la prevención de la trichinellosis. Jornadas de la asociación argentina de parasitología Veterinaria XIX encuentro rioplatense de veterinarios endoparasitólogos.

Ribicich, M., Krivokapich, S., Pasqualetti, M., Gonzalez Prous, C.L., Gatti, G.M., Falzoni, E., Aronowicz, T., Arbusti, P., Fariña, F., Rosa, A., 2013. Experimental infection with Trichinella T12 in domestic cats. Vet. Parasitol. 194, 168-170.

Roig, F.A., Roig-Juñent, S., Corbalán, V., 2009. Biogeography of the Monte Desert. J. Arid Environ. 73, 164-172.

Scrocchi, G.J., Abdala, C.S., Nori, J., Zaher, H. (Eds.), 2010. Reptiles de la provincia de Rio Negro, Argentina. Museo Patagónico de Ciencias Naturales. Fundación Patagónica de Ciencias naturales, Fundación Miguel Lillo, pp. 252.

Stewart, G.L., Kennedy, R.R., Larsen, E., 1990. Infectivity of Trichinella pseudospiralis isolated from carrion. J. Parasitol. 76, 750-751.

Tesón, M., Huici, N., Regis, A., 1997. Triquinelosis en jabalíes en el departamento Lacar. Neuquén. RA. Vet. Arg. 14 (133), 187-190.

Weiss, R.A., 2001. The Leeuwenhoek lecture 2001. Animal origins of human infectious disease. Philos. Trans. R. Soc. Lond. 356, 957-977.

Winter, M., Birochio, D.E., Pasqualetti, M., Fariña, F., Mora, M., Perera, N., Nuñez, M., Ribicich, M.M., 2015. Evaluación de Trichinella spp. en jabalíes (Sus scrofa) obtenidos mediante distintas modalidades de caza en Patagonia noreste. Libro de resúmenes VII Congreso Argentino de Parasitología. pp. 106.

Winter, M., Birochio, D., Alonso, B., Marcos, A., Veneroni, R., Castillo, M., Abate, S., 2016. Circulación de Trichinella spp. entre jabalíes (Sus scrofa) de la Patagonia noreste: resultados preliminares. In: Libro de resúmenes XXIII Congreso Latinoamericano de Microbiología.

Zarlenga, D.S., Rosenthal, B., La Rosa, G., Pozio, E., Hoberg, E.P., 2006. An old genus learns new tricks: late tertiary colonization and speciation of Trichinella nematodes among Eutheria. Proc. Nat. Acad. Sci. 103, 7354-7359. 